\title{
The Treatment of a Dental Morphological Anomaly Type Dens in Dente A challenge
}

\begin{abstract}
KAMEL EARAR ${ }^{1}$, LIANA TODOR ${ }^{2}$, ANCA PORUMB ${ }^{2 *}$
1Dunarea de J os University of Galati, Faculty of Medicine and Pharmacy, 47 Domneasca Str., 800008, Galati, Romania 2University from Oradea, Faculty of Medicine and Pharmacy, Department of Dental Medicine, 10,1 December Sq., Oradea, Romania

Dens in dente or the amelo-dentinal invagination is met rarely and involves, almost in exclusivity, the upper lateral incisisors, usually unilateral, being an invagination in glove finger of the enamel in dentine, on the level of a tooth often dismorphic. The radiologic aspect is of candle flame, occupying the central part of an upper lateral incisor.
\end{abstract}

Keywords: dens in dente, situs inversus, radiography, incisors coronary morphology

Dens in dente is a dental development abnormality resulting from partial invagination of the enamel organ to variable depths, during its development [1]. A number of other therms have also been used to describe it [2]. For example, according to Sutalo et al (2004) [2,3], in 1897 Busch first suggested the use of dens in dente which implies the radiographic appearance of a tooth within a tooth. However, Hunter (1951) suggested the term dilated composite odontome which infers an abnormal dilatation of the dental papila, while Colby (1956) recommands the use of gestant anomaly. Other term frecquently used is dens invaginatus[4]. The varied nomenclature probably reflects the lack of consensus on the formation, aetiology and classification of the condition ( Goncalves et all 2002) $[2,5]$.

The literature suggests several aetiological factors $[2,4,6]$. These are stimulation and subsequent proliferation and ingrowth of cells of the enamel organ into the dental papila; retardation of a focal groups of cells, with those surrounding continuing to proliferate normally during the dental development; external factors like trauma and infections; and also genetic factors $[1,7,8]$.

Various classifications were propose to describe dental invagination[1] Still, the classification of Oehlers, which is based on the radiological criteria, continues to be the most common used $[4,8,9]$. Three invagination category were propose by Oehlers to separate the different types of dens invaginatus by the radiographic appearance of invagination: type I: minimal invagination, enamel lined, confined within the crown of the tooth, and does not extend beyond the level of the external amelocemental junction; type II: enamel lined and extends into the pulp chamber, but remains within the root canal with no communication with the periodontal ligament; type III: the invagination penetrates through the root, perforating the apical area and having a second foramen in the apical or periodontal area, but there is no immediate communication with the pulp [9]. Type I is the most common.

The most frecquently affected tooth is the maxillary lateral incisor $[2,4,10]$. In a decreasing order of frecquency, other teeth that develop this anomaly are: the central maxillary incisor, premolars, canine and molars $[4,10]$. The occurrence of this anomaly in mandibular teeth has been reported in a few cases $[4,6,11,12]$.

Most of the cases of dens in dente are discovered by chance, following an usual radiologic examination with a panoramic radiography or an orthopantomography and completed with a retroalveolar radiography [13].

Clinical, a deep foramen caecum might be the first clinical sign indicated the presence of a dens in dente [14]. According to its morphology, the invagination constitutes a privileged area for plaque formation, being difficult to acces and clean. Moreover, we should not overlook the fact that the thin and hipomineralized enamel also stands out in causing pulpar pathology and complicate any possible endodontic treatment[15, 16-24].

\section{Experimental part}

This paper presents a clinical case diagnosed with the coexistance of no less than 3 anomalies of the dental morphology: dens in dente on the level of the upper central incisor that is a dental anomaly of extra number butalso of structure, and both upper lateral incisors are nanic (infantile), namelya dental anomaly of less volume. A plus of dificulty is brought also by the fact that the patient from this case report is a child.

The patient, a 14-years-old girl, presented in our clinic acusind recent pains on the level of 1.1

The clinical examination (fig.1) and treatment was conducted with the written informed consent of her mother who was also instructed regarding our intention to include this case in a scientific paper.

\section{Radiological examination}

Orthopantomography performed at the presenting of the patient in our clinic reveals the presence in the oral cavity of all the definitive theeth, then intrabony the buds of the teeth $18,2.8,3.8$ oi 4.8 with the crowns completely mineralized, and at the level of 1.1 dens in dente.

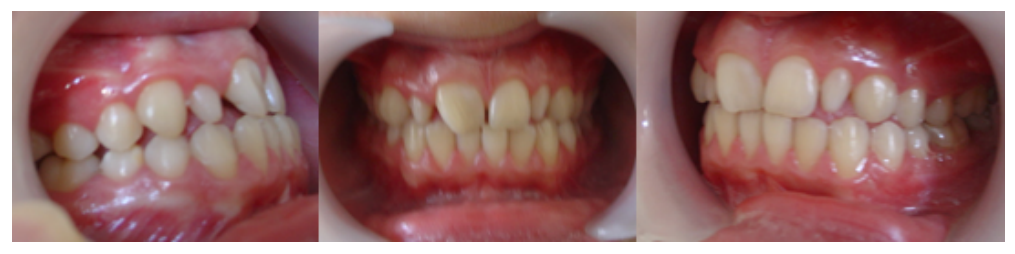

Fig. 1. Lateral right, frontal and lateral left oclussion

*email :anca.porumb@yahoo.com, Phone +40(0) 726286237 


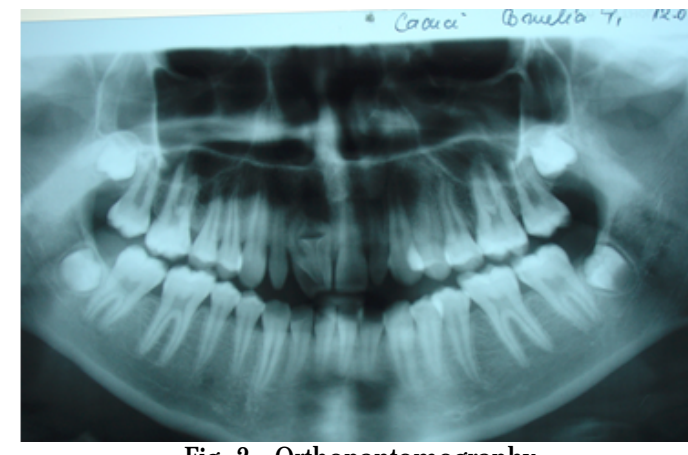

Fig. 2. Orthopantomography

On the level of 1.1 toth is performed a new radiography (fig. 3) retroalveolar, isometric and orthoradial for the detailed prominence of the supernumerary. With this occasion, is determined that the suernumerary is also in position of situs inversus. The retroalveolary radiograhy is repeated, this time w th digital sensor, with the needles on the channel and, then at the end of the endodontic treatment.

\section{Results and discussions}

The case suscitates interest by the cohexistance in the oral cavity of a paient of no less than 3 anomalies of the dental morphology: dens in dente at the level of the upper central incisor that is a dental anomaly of extra number and of structure, and both upper lateral incisors are nanic (infantile), namely a dental anomaly of less volume.

The case presents interestalso from the point of view of the localization and namely not at an uper lateral incisor, as is most frequently met in the specialty literature, but at an upper central incisor.

Most of the cases of dens in dente are discovered by chance, following an usual radiologic examination performed with a panormaic radiography or an orthopantomography that brings general information and completed with a retroalveolar radiography that will offer detailed information: in our case on the retroalveolar radiography we observe the situation of the super numerary in situs inversus.

Subiectively, the patients with dens in dente can come for acute pain and inflamation.

The radiological examination performed during the endodontic treatment with needles on the chanel is offering precious information regarding the morphology and radiological anatomy of a dens in dente, the endodontic treatment in dens in dente can be complicated.

The radiological examination will be made again at the end of the channel obturation in order to be underlined its correctitude.

We remark the importance of the radiological examination in such a case, this being performed at the beginning of the endodontic treatment, during the treatment with needles on chanel and of control a the end of the channel obturation.

The remaking of the coronary morphology can be performed only after the patient will have the age of 18. This will concern the improvement of the physiognomic aspect of the patient by the remaking atnormal dimensions of the crown of the teeth 1.2 and 2.2.(nanic) and by coronary remodeling at 1.1

After the age of 18, will be reduced the coronary volume of 1.1 , and at 1.2 and 2.2 will be added composit material for the remaking at normal dimensions of the crown of the 2 nanic upper laterial incisors or will be used the facets, metalic ceramic crowns or totally ceramic.

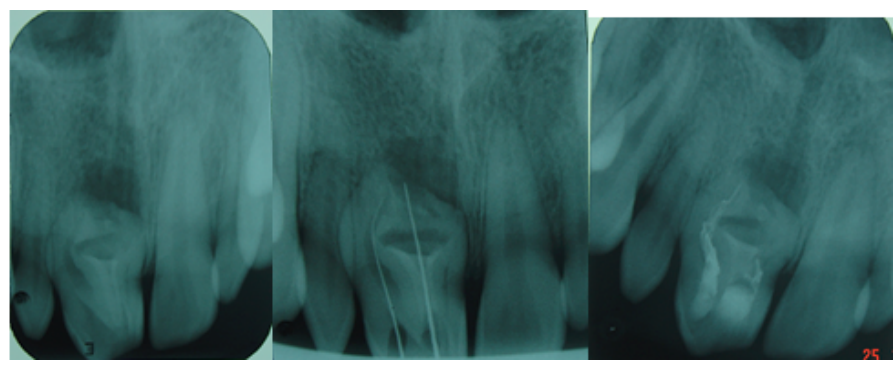

Fig. 3. Retroalveolar radiographies

\section{Conclusions}

In the presentation of this case report, the authors intended to highlight the dificulty of the treatment in such a case of dens in dente, the challenge being that the supernumerary tooth was situated in position of situs inversus.

The case presents interest also from the point of view of the localization and namely not at an uper lateral incisor, as is most frequently met in the specialty literature, but at an upper central incisor.

We remark, hence, the importance of the radiological examination in such a case, this being performed at the beginning of the endodontic treatment, during the treatment with needles on chanel and of control a the end of the channel obturation.

The treatment of such a case of dental morphologic anomaly of dens in dente type can be a challenge for any experienced practitioner.

\section{References}

1.LEJ RI W, KALLER I, MARWEN O, DOUKI N., Diagnostic and therapeutic approach in dens in dente. Endodontology 2016; 28: 192-8.

2.ALANI A, BISHOP K., Dens invaginatus. Part 1: classification, prevalence and aetiology. International Endodontic Journal, 41, 11231136,2008

3.SUTALO J, KNEZEVIC A, NEGOTEVIC-MANDIC V., Endodontic treatment of dens invaginatus: case report. Acta Stomatology Croatia 38, 215-8, 2004

4.DILEK HELVACIOGLUYIGIT, SEDA AYDEMIR.,Endodontic treatment of type II dens invaginatus in a maxillary lateral incisor: a case report; Hindawi Publishing Corporation Case Reports in Dentistry, volume 2012, article ID 153503, 4 pages, doi: 10.1155/2012/153503

5.GONCALVES A, GONCALVES M, OLIVEIRA DP, GONCALVES N., Dens invaginatus type III: report of a case and 10-year radiographic followup. International Endodontic J ournal 35, 873-9, 2002

6.MONTEIRO-JARDEL CC, ALVES FRF., Type III dens invaginatus in a mandibular incisor: a case report of a conventional endodontic treatment; Oral Surgery, Oral Medicine, Oral Pathology and Endodontology, vol 111, nr 4, pp e29-e32, 2011

7.KIMURA R, YAMAGUCHI T, TAKEDA M, KONDO O, TOMA T, HANEJI $K$ et al: A common variation in EDAR is a genetic determinant of shovel-shaped incisors. Am J Hum Genet 2009; 85: 528-35 8.SKRINJ ARIC T, GORSETA K, SKRINJARIC I LOBODONTIA: Genetic entity with specific pattern of dental dysmorphology. Ann Anat 2016; 203: $100-7$

9.OEHLERS F.A.C: Dens invaginatus (dilated composite odontome) Variations of the invagination process and associated anterior crown forms; Oral Surgery, Oral Medicine, Oral Pathology, vol 10, no 11, pp. 1204-1218, 1957

10.VIER-PELISSER F.V, PELISSER A, RECUERO L.C, SO M.V, BORBA M.G, FIGUEIREDO J .A: Use of con beam computed tomography in the diagnosis, planning and follow-up of a tpe III dens invaginatus case; International endodontic journal vil 45, pp 198-208, 2012.

11.CARVALHO-SOUSA B, ALMEIDA-GOMES F, GOMINHO L, ALBUQUERQUE D: Endodontic treatment of a periradicular lesion on an invaginated type III mandibular lateral incisor, Indian Journal of Dental Research, vol 20, no.2, pp.243-245, 2009 
12.GEORGE R, MOULE A.J , WALSH L.J : A rare case of dens invaginatus in a mandibular canine; Australian Endodontic J ournal, vol 36, no.2, pp.83-86, 2010

13.BRAD, S. : Diagnosticul radioimagistic dento-maxilar, Editura Mirton, Timi-oara, 2003, pg. 128.

14.REDDY Y.P, KARPAGAVINAYAGAM K, SUBBARAO C.V: Management of dens invaginatus diagnosed by spiral computed tomography: a case report; Journal of endodontics, vol 34, no.9, pp. 1138-1142, 2008 15.JUNG M: Endodontic treatment of dens invaginatus type III with three root canals and open apical foramen; International Endodontic Journal vol 37, no.3, pp.205-213, 2004

16.J ARAMILLO ALEJANDRO, RAFAEL FERNANDEZ, VILLA PAULA : Endodontic treatment of dens invaginatus: A 5-Years follow-up, Colombia , 2005

17.ANTOHE, M.E., AGOP FORNA, D., DASCALU, C.G., Implications of digital image processing in the paraclinical assessment of the partially edentated patient, Rev.Chim.(Bucharest), 69, no.2,2018 pg.521-524

18. NASH,D.,RUOTOISTENMAKI,] ., ARGENTIERI,A.et al.,Profil of the oral healhcare team in countries with emerging economies, Conference Global Congress on Dental Education Iocation, Dublin,Ireland, European J ournal of Dental Education,12((1), 2008, pg.111-119
19. IFTENI,G., APOSTU,A., TANCULESCU,O., Dental occlusion and the importance of is proper investigation-partll, Romanian Journal of Oral Rehabilitation, 8(4),2016,p.17-22

20.BALAN, G., GRIGORE, C.A., BUDACU,C.C., et al., Antisepsis, Desinfection Sterilization-mehods used in dentistry, Rev.Chim. (Bucharest), 68, no.1, 2017, p.186-191

21.ZEGAN, G., DASCALU, C.G., MAVRU, R.B., Cephalometric, features of Class III malocclusion, Medical-surgical journal,119(4), 2015, 11531160 ;

22.ANCUTA ,C., POMIRLEANU, C., IORDACHE,C., et al., Serum lipid profile in diffuse versus limited systemic sclerosis data from the SASS cohort, Rev.Chim.(Bucharest), 69, no.2, 2018, p.403-406

23.IORDACHE, C., GHIORGE,C.A., ANTOHE M.E., et al., Temporomandibular joint involvement in rheumatoid arthritis and ankylosing spondylitis:a cross-sectional study, 994,2017, p.40-46

24. DASCALU, C.G., CARAUSU, E.M., MANUC, D., Methods for Data Selection in Medical Databases: The Binary Logistic Regression Relations with the Calculated Risks, Proceedings of world academy of science, engineering and technology, VOL 28 Book Series: Proceedings of World Academy of Science Engineering and Technology Volume: 28 Pages: 278-+Published: 2008

$\overline{\text { Manuscript received:21.10.2018 }}$ 